\title{
1. Services in global value chains and new patterns in global services trade
}

\subsection{THE ROLE OF SERVICES IN INCREASINGLY 'SERVICIFIED' GLOBAL VALUE CHAINS}

\subsubsection{Services in Global Value Chains}

These days, countries no longer participate in international trade merely by exporting final products, but also by specializing in various stages of the manufacturing process. Those various stages can be connected to become 'value chains' - a notion delineating 'the sequence of activities that firms undertake to create value, from the conception of a product to its manufacturing and commercialization'. ${ }^{1}$ Participating in one or several stages in such value chains enables a country to utilize its comparative advantages. In addition, by focusing on specific tasks and integrating into highly systematic business models, such chains of related activities may help firms create more added value, even exceeding 'the sum of the value of the constituent parts and processes'.

In the stylized model, value chains often start with upstream services activities, namely research and development (R\&D) or design, run on through processing or assembly, before ending with more downstream activities (e.g., marketing, brand management, or post-sales services). The activities at the two ends of the chains are normally more value and intellect-intensive ones, whereas those in the middle of the chains are often standardized and tend to generate less added value. ${ }^{3}$ As globalization enables firms to restructure their

1 WTO and IDE-JETRO (2011), Trade Patterns and Global Value Chains in East Asia: From Trade in Goods to Trade in Tasks (Geneva: WTO Publications), at 115. The report is available at: https://www.wto.org/english/res_e/booksp_e/stat_tradepat _globvalchains_e.pdf (visited 20 February 2018).

2 Ibid, at $1 \overline{0}$.

3 Swedish National Board of Trade (SNBT) (2013), Global Value Chains and Services - An Introduction (Stockholm: National Board of Trade), at 8. The report is available at: https://www.kommers.se/Documents/dokumentarkiv/publikationer/2013/ rapporter/report-global-value-chains-and-services-an-introduction.pdf (visited 25 June 2019). 
operations on an international scale by slicing up and optimizing the value chains through outsourcing or offshoring certain activities to various companies across different geographical locations, the term 'global value chains' (GVCs) has been coined. ${ }^{4}$ It has become a feature of international production, trade and investment to be organized within GVCs whose different stages of the production process are located across different countries. ${ }^{5}$ This feature is also defined by other related terms, such as global production sharing, trade in tasks, offshoring, fragmented production, vertical specialization, etc. ${ }^{6}$

New literature on GVCs has urged a reconsideration of the role of services in the world economy, which has long been underrated. ${ }^{7}$ As the notion of GVCs takes into account 'the sequences of value added within an industry, from conception to production and end use', it reveals that 'services and manufacturing activities are intertwined' ${ }^{8}$ Thus, services are not only essential to GVCs in the same manner as goods are (i.e., they are meant for both end consumption and as inputs for making other products or services), but they also assume distinctive roles in GVCs.

Services serve as links in GVCs: As GVCs represent a higher level in the international division of labor, in order to manage geographically fragmented production processes, firms rely on many services, namely transportation, communication, logistics, finance, etc. It means the first role of services in GVCs is to connect manufacturing activities across territories. It is possible

4 See WTO and IDE-JETRO, supra note 1, at 10 and 115. The report describes offshoring as an enterprise's decision to contract the supply of specific goods or services to foreign suppliers, who can be independent or affiliated firms. Meanwhile, outsourcing describes an enterprise's decision to acquire specific inputs from an outside (unaffiliated) firm, instead of internally producing them. Therefore, offshore-outsourcing is a special form of outsourcing, where the contractual parties are not present in the same country.

5 Organization for Economic Co-operation and Development (OECD), Global Value Chains, available at: http://www.oecd.org/sti/ind/global-value-chains.htm (visited 23 October 2019).

6 SNBT (2012), Everybody is in Services - The Impact of Servicification in Manufacturing on Trade and Trade Policy (Stockholm: National Board of Trade), at 11, available at: https://www.kommers.se/Documents/dokumentarkiv/publikationer/ 2012/skriftserien/report-everybody-is-in-services.pdf (visited 23 October 2019).

7 See, among other papers, Antoine Gervais and Bradford Jensen (2013), 'The Tradability of Services: Geographic Concentration and Trade Costs', National Bureau of Economic Research Working Paper Series No. 1975, available at: http://www.nber .org/papers/w19759.pdf (visited 23 October 2019).

8 Sébastien Miroudot (2017), 'The Servicification of Global Value Chains: Evidence and Policy Implications', UNCTAD Multi-year Expert Meeting on Trade, Services and Development (Geneva, 18-20 July 2017), at 1. 
to think of services as the 'glue' in GVCs, without which GVCs will cease to exist. ${ }^{9}$

Services serve as outsourced inputs in GVCs: Apart from being support functions that enable GVCs, services are 'crucial inputs in key stages of production' as well. ${ }^{10} \mathrm{~A}$ value chain may begin with, for instance, $\mathrm{R} \& \mathrm{D}$ or design activities, and end with marketing or distribution activities. All these activities are 'per se important production stages'. ${ }^{11}$ Once these activities are outsourced, they are obviously service inputs. Notably, some of these service inputs are horizontal, which are crucial for all types of firm in all GVCs (e.g., accounting and legal services). Whereas, other services are vertical, which means they are industry specific (e.g., portfolio research in the banking and finance sector). ${ }^{12}$

Services serve as in-house inputs in GVC: This role arises from functions inside firms. It is a common practice for firms to generate their own support services in-house, e.g., infrastructure management activities. Although such activities are usually considered as part of the firms' functions, they are in fact service inputs self-supplied by the firms instead of being outsourced. It implies that 'services are produced not only by services firms, but also by manufacturing firms'. ${ }^{13}$ Thus, the recognition of services supplied in-house is necessary to fully assess 'the impact of services on trade and value creation'. ${ }^{14}$

Services are bundled with goods sold by manufacturing firms: This role of services in GVCs arises from the fact that manufacturing firms at times do not sell goods alone, but sell them along with services. For example, machinery may be exported in a bundle with installation and maintenance services. This type of services often helps buyers to make use of the goods, either at the time of importation or later in the operation stage. Firms are inclined to sell such bundles as it enables them to generate more value from core goods and create long-term relationships with customers. For customers, bundled services are tempting as they often help to cut costs, and domestic alternatives are not always available. In some cases, accompanying services may even become

9 Sébastien Miroudot and Charles Cadestin (2017), 'Services in Global Value Chains: From Inputs to Value Creating Activities', OECD Trade Policy Papers No. 197 (Paris: OECD Publishing), at 9.

10 Cecilia Heuser and Aaditya Mattoo (2017), 'Services Trade and Global Value Chains', in David Dollar, Jose Reis and Zhi Wang (eds), Measuring and Analyzing the Impact of GVCs on Economic Development (Washington, DC: World Bank Publications) 141-59, at 143.

11 See Miroudot and Cadestin, supra note 9, at 9.

12 Gary Gereffi and Karina Fernandez-Stark (2010), 'The Offshore Services Value Chain: Developing Countries and the Crisis', World Bank Policy Research Working Paper Series No. 5262, at 5.

13 Heuser and Mattoo, supra note 10, at 143.

14 See Miroudot and Cadestin, supra note 9, at 10. 
requisite for the sale of goods. ${ }^{15}$ This role reinstates that manufacturing firms are responsible for a remarkable share of services sales and exports. Therefore, it is quite artificial for trade statistics to distinguish between firms producing goods or producing services. ${ }^{16}$

Though all bundled services to a certain extent share the same purpose of comforting customers upon the purchase of products, they are further divided into two types. The first type of services will smooth the sale or use of goods without significantly altering its functionality, while the second type may expand their functionality. A basic training service offered by the manufacturer exemplifies a 'smoothing' service; whereas major customization creating customer-specific features to a product portrays an 'adapting' service. In addition, not all product-related services provided by manufacturing firms are complementary. In fact, they may also be a 'substitute' for the sale of the good, e.g., rental services provided in lieu of cars. ${ }^{17}$

Whether services serve as inputs for production, as in-house activities within firms, or as complementary services to exported goods, the commonality is that they enable manufacturing firms to generate value. ${ }^{18}$ As discussed above, there will be no GVCs in the absence of services connecting the globally dispersed production stages. Arguably, it is the 'linking services' that pave the way for value creation within GVCs, resulting in more value created through the whole GVC than the aggregated value at each of these stages. In cases where services are used as inputs, the added value comes either from these inputs themselves, or from the costs saved if they are outsourced. To be specific, some service inputs such as legal or banking services may help manufacturing firms create value via improving their operations and productivity. Whereas, other services namely transport or logistics services may allow firms to cut costs as they are less costly when outsourced thanks to the external providers' economies of scale. Likewise, investing in in-house services may also allow firms to create value, particularly if the self-supply is less costly, or if it is crucial to maintain the competitive advantage. ${ }^{19}$ Last but not least, providing complementary services may improve the organization of firms and bring a new source of income, and at the same time create more value for consumers by offering them cost-saving tailored solutions. ${ }^{20}$

\section{Ibid.}

See Miroudot, supra note 8, at 2.

7 Michael Cusumano, Steven Kahl and Fernando Suarez (2014), 'Services, Industry Evolution and the Competitive Strategies of Product Firms', 36(4) Strategic Management Journal 559-75, at 562-3.

18 See Miroudot and Cadestin, supra note 9, at 11.

19 Ibid, at $11-12$.

20 Ibid, at 12 . 


\subsubsection{The Servicification of GVCs}

\subsubsection{The concept of servicification}

While production of goods and provision of services used to be thought of as separate spheres, the rise of GVCs indicates that they are actually interconnected: services are increasingly used as inputs for production in manufacturing industries, and firms are producing and providing more services besides tangible products. ${ }^{21}$ This is part of the cause of the phenomenon known as 'servicification of manufacturing'. In essence, this phenomenon 'highlights the increasing complementarity between the manufacturing of goods and the provision of services'. ${ }^{22}$

To be precise, servicification is not a new phenomenon because the growing important role of services in the economy has been analyzed for a long time. Literature on servicification dates back to the work of Levitt in early 1970s, asserting that there are "no such things as service industries. There are only industries whose service components are greater or less than that of other industries. ${ }^{23}$ By late 1980s, Vandermerwe and Rada devised the term 'servitization' to depict the trend of manufacturing firms supplying more and more services. ${ }^{24}$ However, the evolvement of GVCs in recent decades has brought new lenses to document the role of services in manufacturing industries. This is absolutely important to understand servicification because the phenomenon is by nature related to GVCs: the latter operate via the deployment of services. Servicification occurs at all stages of a typical GVC. In the first stage (preproduction and inputs), servicification is mainly caused by a relative rise in the value of services as compared to tangible inputs. This is because various knowledge and value-intensive business services (e.g., finance, insurance, or communications) are vital for sophisticated industries. In the next stage (manufacturing and assembly), servicification comes about owing to the fact that this stage is growingly digitalized, which means it is partly or fully supported or controlled by digital services. In the third stage (output and after-sale), servicification takes place when services are sold by manufacturing firms to

21 See Miroudot, supra note 8, at 2.

22 SNBT (2015), Servicification on the Internal Market - A Regulatory Perspective (Stockholm: National Board of Trade), at 6. The report is available at: https://www .kommers.se/Documents/In_English/Report-Servicification\%20on\%20the\%20Internal $\% 20$ Market $\% 20 \%$ E2\%80\%93\%20a\%20regulatory\%20perspective.pdf (visited 24 October 2019).

${ }_{23}$ Theodore Levitt (1972), 'Production-line Approach to Service', 50(5) Harvard Business Review 20-31, at 1. The paper is available at: https://hbr.org/1972/09/ production-line-approach-to-service (visited 19 July 2019).

${ }^{24}$ Sandra Vandermerwe and Juan Rada (1988), 'Servitization of Business: Adding Value by Adding Services’, 6(4) European Management Journal 314-24. 
customers, either embodied into the products or alongside the products. ${ }^{25}$ It explains why a number of authors employ the term servicification to describe 'the broader shift towards services not only in sales of firms but also in the way they produce'. ${ }^{26}$

In this book, the concept of servicification conveys the notion that 'the manufacturing sector is increasingly relying on services, whether as inputs, as activities within firms, or as output sold bundled with goods' ${ }^{27}$ To be specific, servicification encompasses: (1) the increased use of services as inputs, resulting in a higher share of added value from service industries; (2) the shift towards service activities within manufacturing firms; and (3) the convergence of goods and services sold in bundles by manufacturing firms that are increasingly servicified. ${ }^{28}$

\subsubsection{Measuring servicification from a 'trade in value added' perspective}

\subsection{Trade in value added}

Traditional trade statistics systems are constructed to quantify economic transactions based on the gross value of trade among partners. As a consequence, they often fail to specify how foreign upstream producers are connected to end consumers. ${ }^{29}$ The rise of GVCs has prompted the development of statistical methods to depict such connection. In essence, trade statistics need to assess value added at each stage of a GVC to reflect the contribution of all primary production factors.

To begin with, the concept of 'trade in value added' (TiVA) is defined as 'an alternative to the traditional measure of international exchanges in goods and services, adapted to the evolution of global supply chains, which enables the domestic content included in gross export flows to be estimated' ${ }^{30}$ It means TiVA scrutinizes the specificity of trade taking place among different actors of a GVC. Unlike traditional statistics that assesses cross-border trade on a gross value basis, which entails the risk of double counting, it records trade flows on a net value basis at each stage of the vertical chain. Accordingly, TiVA enables

See SNBT (2015), supra note 22, at 7-8.

See Miroudot and Cadestin, supra note 9, at 8.

Ibid.

Ibid.

9 David Dollar (2017), Order from Chaos: Global Value Chains Shed New Light on Trade (Washington, DC: Brookings Institution), available at: https://www .brookings.edu/blog/order-from-chaos/2017/07/10/global-value-chains-shed-new-light -on-trade/ (visited on 21 February 2018).

30 See WTO and IDE-JETRO, supra note 1, at 195. 
'the specificity of the new business model behind global manufacturing to be incorporated, complementing usual trade statistics where trade in goods and services is progressively being substituted by trade in tasks'. ${ }^{31}$

To portray the difference between TiVA and traditional trade statistics, let us consider a simplified example on a production chain concerning three parties, which begins in Vietnam and France with the manufacturing of machinery parts to export to Japan. A Japanese firm then combines imported parts with domestic ones and assembles them into a machine to export to France. Manufacturing activities taking place among three parties in this value chain raise the question of attributing the value of the machine to each of them. In conventional statistics, Japan's export to France will be recorded with a value of 100, including the value of components imported from Vietnam and France. This leads to the problem of double counting as the value of intermediates is recorded twice - when the parts are exported from Vietnam and France to Japan, and when the machine is exported from Japan to France. Consequently, the value of Japan's export to France is overstated. In contrast, assessing vertical trade flows in this GVC using value added terms may help to avoid such error. For instance, if the value of the parts imported from Vietnam and France amounts to 55, then Japan's domestic value added in its export to France will be 45 only.

The measuring of various sources of value added in each globally traded product does require huge efforts, which urges statisticians to use an indirect method of estimation. They rely on input-output tables that combine national accounts and bilateral data on goods and services trade to evaluate the value added incorporated in exports and the breakdown of such value into domestic and foreign content. The domestic value added content of exports indicates the aggregated added value contributed by each domestic sector to GVCs, while the foreign value added content of exports portrays trade among countries involved in GVCs. ${ }^{32}$

The database on TiVA constructed by the Organization for Economic Cooperation and Development (OECD) and the World Trade Organization (WTO) is among the initiatives that promote this new approach on trade statistics. The joint initiative addresses TiVA by assessing 'the value added by each country in the production of goods and services that are consumed worldwide'. ${ }^{33}$ Relying on this database, the WTO has built the TiVA and GVCs: Country Statistical Profiles to show the 'contribution of foreign trade

\footnotetext{
Ibid, at 95 .

Ibid, at 96.

33 OECD, Trade in Value Added, available at: http://www.oecd.org/sti/ind/ measuringtradeinvalue-addedanoecd-wtojointinitiative.htm (visited 25 October 2019).
} 
to an economy, the interconnection of national economies within GVCs, and the impacts of the services industry on trade'. ${ }^{34}$

Among various purposes, the assessment of TiVA indicators, particularly the domestic value added content of exports, enables a more accurate depiction of the share of each sector in the production of exports, thereby allows an economy to identify the sources of comparative advantages and competitiveness. TiVA statistics also helps to estimate the contribution of foreign content in one economy's exports, which brings another perspective to analyze the actual impact of international trade on economic growth. It also offers a useful tool to evaluate the effectiveness of trade policy measures affecting GVCs of firms in the era of globalization. ${ }^{35}$

Above all, why does TiVA matter in the analysis on servicification? This new approach to trade statistics enables a more accurate estimation of the actual share of services to the value added incorporated in exports of an economy. Therefore, it brings intuition to the role of services in the export of manufactured goods as well as in total exports. ${ }^{36}$ TiVA statistics may reveal that services account for a larger share in merchandise and total exports (as opposed to the figures suggested by traditional statistics). If the shift from gross-based statistics to value added-based statistics remarkably raises the share of services in the economy, it is inferable that the TiVA approach is ample to testify the servicification phenomenon.

\subsection{Evidence of servicification}

\section{A The INCREASED USE OF SERVICE INPUTS}

The most direct way to examine servicification is to look at the use of services as inputs for production. Some researchers have found that the contribution of services to TiVA terms is not only remarkably larger than that in gross terms, but it is also growing. For instance, Heuser and Mattoo have estimated the share of services in world exports over the period 1980-2009 and realized that whereas in gross terms the share remains at around 20 percent after 30 years, in value added terms it has risen from below 30 percent to more than 40 percent. ${ }^{37}$ The figures resonate with the finding of Miroudot and Cadestin

\footnotetext{
34 WTO (2013), 'Trade in Value Added and Global Value Chains' Profiles Explanatory Notes, at 1. The document is available at: https://www.wto.org/english/res _e/statis_e/miwi_e/Explanatory_Notes_e.pdf (visited 25 October 2019).

35 See WTO ${ }^{-}$and IDE-JETRO, supra note 1 , at 95.

36 Ibid.

37 See Heuser and Mattoo, supra note 10, at 145.
} 
that by 2011 , ' $49 \%$ of the value added in world gross exports originates in the service sector'. ${ }^{38}$

Miroudot and Cadestin elaborate on distinguishing between services exported directly by services firms and those embedded in intermediates for production (the latter may include both domestic and foreign service inputs). By looking at the share of domestic direct value added in exports, the authors contend that while some countries are more specialized in exporting commodities and manufacturing goods, others are considered service exporters. However, in all countries, the domestic indirect and foreign share of value added in gross exports indicates the significance of service inputs (both domestic and foreign) used by exporting firms..$^{39}$

Case studies on the inputs of specific firms also reveal the diversity of services used in the manufacturing sector. To illustrate, it is found that Sandvik Coromant (a Swedish company supplying cutting tools) relies on more than 40 different types of services to operate its GVCs, which spread over almost half of the sectors covered by the General Agreement on Trade in Services (GATS). ${ }^{40}$ In another study, the supply chain of Aromatic - a relatively small company providing ingredients to bakeries - has been analyzed. Although the agro-food industry is among the least servicified ones, the company still counts on 50 types of services to carry out its business activities. ${ }^{41}$

\section{B Service activities Within MANUfacturing FiRms}

Servicification can be measured by quantifying the share of value added originating in service sectors. However, studies tend to neglect in-house services self-supplied within manufacturing. ${ }^{42}$ One reason is that it is difficult to directly measure the value of these services. To circumvent the difficulty, the OECD adopts an indirect method to analyze the labor force performing service activities in manufacturing industries. It has found that in all economies, employment in manufacturing industries accounts for a rather small share of

\footnotetext{
38 See Miroudot and Cadestin, supra note 9, at 13.

39 Ibid, at 13-15.

40 SNBT (2010), At Your Service - The Importance of Services for Manufacturing Companies and Possible Trade Policy Implications (Stockholm: National Board of Trade), at 4. The report is available at: https://www.kommers.se/Documents/ dokumentarkiv/publikationer/2010/skriftserien/report-2010-2-at-your-service.pdf (visited 7 November 2019).

${ }^{41}$ SNBT (2013), Just Add Services: A Case Study on Servicification and the Agri-Food Sector (Stockholm: National Board of Trade), at 9-12. The report is available at: https://www.kommers.se/Documents/In_English/Publications/PDF/Just-Add -Services.pdf (visited 7 November 2019).

42 See Miroudot and Cadestin, supra note 9, at 8.
} 
total employment, and between 25 percent and 60 percent of manufacturing employment is indeed working in service functions. ${ }^{43}$

The difference across economies is explained firstly by the sectoral composition. Core manufacturing activities account for a higher share of employment in those industries with low technology content such as textiles and apparels, while technology-intensive industries, namely electronics or information and communications technologies (ICT), require more supporting services, resulting in a higher share of employment in service activities. ${ }^{44}$ In addition, patterns across countries are also influenced by the roles they play in value chains. Developed economies often feature a higher share of employment in 'headquarters' services', which are in-house by nature. It is why certain countries such as Luxembourg, Sweden, or Germany have a higher share of manufacturing employment performing service activities. ${ }^{45}$

It is arguable that employment data may indicate the higher number of jobs in service activities, but not necessarily the contribution of those activities in value added terms. To address this concern, data on wages is important to estimate the value added by in-house services, and the general contribution of both in-house and outsourced services to the manufacturing sector. The OECD has found that once expressed in value added instead of as the number of jobs, the role of in-house services is even more significant. Jobs related to service functions are presumably more high skilled, thus account for a larger share of labor compensation. On average, in-house services account for around 15 percent of gross exports of manufacturing industries. It is also found that in all countries, there are more services outsourced (both domestic and offshore) than insourced. This is reasonable considering the various types of services that a manufacturing firm needs to sustain its business activities. It is not practical to self-provide all these services, so a majority of them need to be outsourced, particularly if they rely on expertise or skills that are too costly for internal provision, or if they require infrastructure or networks that can only be operated outside the firm. ${ }^{46}$

In the manufacturing sector alone, on average 15 percent of the value added in gross exports of manufactured products originates from services supplied in-house. ${ }^{47}$ Thus, once the in-house provision of services is taken into account, the contribution of services to the value of manufacturing exports in the economies covered by the OECD's research has risen from 37 percent to 53 percent. Simply put, over half of the value added in the manufacturing sector comes
Ibid.
Ibid.
Ibid, at 9 .
Ibid, at 21.
47 Ibid. 
from services activities, much higher than the ratio of one-third recorded by traditional statistics. In fact, after adding exports of services firms, the overall share of services' value added in gross exports is close to two-thirds. ${ }^{48}$ The figure is even more remarkable considering the fact that world exports of commercial services have reached 5.77 trillion US dollars in 2018, up from 3.95 trillion in $2008 .{ }^{49}$

\section{SERvices SOld BUndLED With GOOdS}

Services within manufacturing firms are not only used as inputs for, or to support the manufacturing process, but also to be bundled with the goods sold to customers. This role of services in GVCs is even more difficult to measure. In theory, trade statistics is built upon a strict separation between goods and services, so a bundle as such must be recorded as two separate transactions in the balance of payments. In reality, it is often not that clear because there is only one single contract or transaction. While industry-level data can record the sales or exports of services by manufacturing firms, it cannot isolate the value of services sold bundled with goods. ${ }^{50}$

Miroudot and Cadestin attempt to provide evidence on manufacturing activities which are linked to the supply of services by examining the number of firms involved only in manufacturing activities, only in service activities, or in both. The authors realize that in almost all countries, the largest number of firms are found in the service sector and they only supply services. This group consists of many small firms providing retailing, food and accommodation, and other small-scale services. Firms in the manufacturing sector are generally larger and fewer, whereas firms supplying both goods and services come as the second largest group in various countries. ${ }^{51}$

Unlike what traditional statistical separation suggests, it is common for the same firm to perform both manufacturing and distribution activities. Most remarkably, a variety of service activities related to distribution are at times sold bundled with goods. More and more manufacturing firms are supplying transport services, particularly when the delivery of the goods requires specific technologies or skills from an industry, such as pipelines in the gasoline industry. This reason may apply to warehousing and storage services, or services related to waste recycling and material recovery as well..$^{52}$ Besides

\section{Ibid, at 40 .}

WTO (2019), World Trade Statistical Review (Geneva: WTO Publications), at 154, available at: https://www.wto.org/english/res_e/statis_e/wts2019_e/wts2019_e .pdf (visited 13 January 2020).

50 See Miroudot and Cadestin, supra note 9, at 22.

$51 \quad$ Ibid, at 24.

52 Ibid. 
distribution-related services, which are essential for the operations of GVCs, there are other bundled services that are indispensable to sell goods. For example, construction services are indispensable in the wood product industry because the sale of woods may not happen if it is not part of a construction contract. Likewise, in the machinery industry, maintenance or installation services are deemed indispensable because without them, firms may not be able to sell the machines they manufacture..$^{53}$

Although they are not bundled with goods, the group of services being 'substitutes' for goods also reflects the trend of servicification. Some firms have switched to a business model in which they rent the product instead of selling it. Other firms have decided to focus on providing services instead of manufacturing goods since the former becomes more profitable than the latter over time. ${ }^{54} \mathrm{IBM}$ is one famous example: the company, originally a hardware producer, has moved up in its GVC to redefine itself as a business solutions provider which supplies 'an industry-leading portfolio of consulting, delivery and implementation services, enterprise software, systems and financing'. ${ }^{55}$

\section{BOX 1.1 SERVICIFICATION AND 'MODE 5' SERVICES}

The concept of servicification gives rise to the argument that the GATS' four modes of supply fail to capture a sizable and growing share of services incorporated in physical goods circulated across the world. In the case of European Union (EU), this category of services 'accounts for 34\% of manufacturing and primary sectors' exports' ${ }^{56}$ The revelation has prompted some pioneer authors to propose a hypothetical mode of supply - 'Mode 5'.

What is the coverage of 'Mode 5' and how is it relevant to servicification? By definition, 'servicification' refers to the phenomenon of manufacturing firms using more services at all stages along their GVCs. Thus servicification includes service inputs, production and post-sales services, which indeed cover the whole life cycle of a product. Whereas, the notion of 'Mode 5' narrates production services embodied in the manufacturing of a physical

\section{Ibid.}

54 Ibid, at $10-11$

55 Zahir Ahamed, Takehiro Inohara and Akira Kamoshida (2013), 'The Servitization of Manufacturing: An Empirical Case Study of IBM Corporation', 4(2) International Journal of Business Administration 18-26, at 21.

56 Lucian Cernat and Zornitsa Kutlina-Dimitrova (2014), 'Thinking in a Box: A "Mode 5" Approach to Service Trade', 48(6) Journal of World Trade 1109-26, at 1114. 
product. Accordingly, 'Mode 5' services 'are domestic intermediate services inputs incorporated in one country's merchandise exports'. ${ }^{57}$ For example, to produce cars, a company may need consulting, design, engineering, as well as logistics services to buy inputs and organize the production chain. These 'Mode 5' or embodied services differ from embedded services, which are ones related to the sales of a good or another service such as post-sales support, technical assistance, and maintenance. The reason is that the latter can be provided via one of the four traditional supply modes, so they are excluded from the coverage of 'Mode 5'. To be precise, 'Mode 5' services represent a subset of servicification, covering domestically produced services which constitute a component of an exported good's value.

An essential feature of 'Mode 5' is its simultaneous relation 'to goods and services, as it focuses on the interrelation between merchandise and services trade' ${ }^{58}$ Besides, many 'Mode 5' services (e.g., architecture, design, engineering, and R\&D) are value-intensive and closely linked to technology. To cite just one example, 90 percent of the EU's exports are intensive in intellectual property ${ }^{59}$ For this reason, these services are often essential to embrace the competitive advantages of manufacturing firms.

Cernat and Kutlina-Dimitrova measure the size of 'Mode 5' services by assessing their share in gross merchandise exports. They find that it ranges between 20 percent (China) and 34 percent (EU). In absolute value, the EU's 2009 'Mode 5' services exports are estimated to exceed 300 billion euros. Noticeably, there is a trend of growth in 'Mode 5' exports: as compared to 1995, the share of 'Mode 5' in the EU's 2009 gross exports has increased by 23 percent, and that in the United States (US) has risen by 37 percent over this period. ${ }^{60} \mathrm{~A}$ most recent research by Borchert and Tamberi reveals that the value of domestic service inputs into the United Kingdom's (UK's) manufacturing exports amounts to over 70 billion pounds in $2017 .^{61}$

\footnotetext{
Ibid, at 1116.

Ibid, at 1115 .

Ibid, at 1116 .

Ibid, at 1117 .

1 Ingo Borchert and Nicolo Tamberi (2018), 'The Engagement of UK Regions in Mode 5 Services Exports', UK Trade Policy Observatory Briefing Paper 22, available at: http://blogs.sussex.ac.uk/uktpo/files/2018/09/Briefing-Paper-22a-1.pdf (visited 18
} January 2020). 


\subsection{THE INTERNATIONALIZATION AND DIGITALIZATION OF TRADE AND PRODUCTION}

Internationalization and digitalization are modern trends of trade and production that are intertwined with servicification. On one hand, they are components of this broader trend; on the other hand, they can be categorized among the drivers thereof.

\subsubsection{Internationalization of the Supply of Services Inputs}

The emergence of GVCs has brought the possibility of "international specialization not only in final goods and their parts, but also in services and service tasks'. ${ }^{62}$ Apart from the role as enablers in GVCs, services are disaggregated into separate tasks and traded in a way similar to tangible inputs. In GVCs, not just the assembly of goods but various other service-related tasks have also been outsourced or offshored. As a matter of fact, 'offshore outsourcing of services is occurring all over the value chain, from low value added transaction processing or call centers to activities with high intellectual capital content such as software programming, design, engineering, accounting, actuarial expertise, legal and medical advice, and a broad array of business consulting functions'. ${ }^{63}$ There are different causes driving the trend: in some cases, offshoring is a means to cut costs; in other cases, it is to gain from expertise not available domestically. By and large, the offshoring of services to lower-cost foreign suppliers is expected to boost productivity since each economy can focus on its comparative advantage. Higher specialization will also bring new opportunities for emerging suppliers. ${ }^{64}$

The OECD estimates that the share of services in world TiVA terms has increased between 1995 and 2009, then decreased due to the financial crisis. Thus, the total services value added in gross manufacturing exports at the aggregate level is not convincing evidence of servicification in terms of inputs. However, all manufacturing industries have higher shares of foreign services value added over this period whereas the domestic services value added decreases, except in certain industries such as food, wood products, papers, print and publishing and utilities. The increased use of foreign services shows

62 See Heuser and Mattoo, supra note 10, at 142.

63 Stephen Roach (2004), 'How Global Labor Arbitrage Will Reshape the World Economy', Global Agenda (the Magazine of the World Economic Forum Annual Meeting), available at: http://ecocritique.free.fr/roachglo.pdf (visited 10 January 2020).

64 See SNBT (2013), supra note 3, at 8. 
that the offshoring of services tasks has occurred in most industries. It is, therefore, more precise to discuss the internationalization of inputs rather than the servicification thereof. ${ }^{65}$

To illustrate, in China, a country with relatively low direct services exports, the indirect inputs does account for almost one-third of the value of services exports, half of which comes from foreign services inputs. This implies that countries specializing in services may include even higher foreign services content in their services exports. ${ }^{66}$ The OECD concludes that, with the exception of China and the Philippines who choose to increase domestic service inputs, the trend of internationalization of service inputs takes place in all other countries. $^{67}$

The data from WTO-OECD shows that over the period from 1995 to 2011, over 65 percent of the rise of services value added in exports is brought by a growth in services embodied in other exports. Although the growth is found in both domestic and foreign embodied services, the latter has grown more rapidly. This fact indicates that an increased share of embodied services is sourced overseas, which is an evidence of internationalization. The authors emphasize that since statistics in merchandise trade are recorded on a cross-border basis, the value added of foreign services supplied under Mode 3 is reflected in the domestic category. Hence, the above statistics probably still understate the share of foreign services value added in exports (and the trend of internationalization). ${ }^{68}$

Another evidence of the internationalization trend is found in the rise of service GVCs. Until now analysis has focused on services used by or produced within manufacturing industries. To complete the analysis, it is crucial to consider how service industries are organized. ${ }^{69}$ There is limited research on 'pure' service GVCs but it is evident that such GVCs 'are created in a variety of service sectors, namely banking, tourism, audiovisual, and possibly education and health services, as well as business processing services'. ${ }^{70}$

While the various stages in services value chains may resemble conventional ones, the value added in each stage is likely to differ. In a number of sectors, firms have widened the range of services they provide and created new types of connection with customers. In the view of Stabell and Fjelstad, the term 'value chain' should be used to describe an industry in which 'products move sequen-

\footnotetext{
See Miroudot and Cadestin, supra note 9, at 16.

See Miroudot and Cadestin, supra note 9, at 13-15.

Ibid, at 17.

See Heuser and Mattoo, supra note 10, at 146.

See Miroudot and Cadestin, supra note 9, at 28.

See SNBT (2013), supra note 3, at 9.
} 
tially from upstream to downstream, adding value at each stage' ${ }^{71}$ Thus, it is argued that certain industries (e.g., construction and food services) do conform with such linear model; however, for most industries, this is not necessarily true. For this reason, the authors instead suggest two other modalities of value creation. A modality is 'value network', which generates value through linking customers. To illustrate, value is created in the insurance industry by having a number of customers share the risks to cover the damage of just a few. There are also network-based services where the networks are physical, and the value is created thanks to the linking and sharing of infrastructure, e.g., telecommunications and transport services. The other modality that may portray value creation in a number of services industries is 'value shop', in which value is acquired via settling the customers' problems. Unlike value chains which rely on standard processes, tailored solutions are indispensable for value shops. Plausibly, consultancy or R\&D services are proper examples for this value creation modality. ${ }^{72}$

Baldwin and Venables concur with this view and make a vivid comparison assimilating service GVCs with 'spiders' - as opposed to 'snakes' which describe conventional value chains. ${ }^{73}$ In its essence, the concepts of value networks and value shops may broaden the set of business models that policymakers should have in mind when dealing with GVCs to avoid the simple perception of GVCs as 'the pure manufacturing value chains with a sequential production' ${ }^{74}$

While service GVCs are generally shorter than those of goods, there is fragmentation and internationalization of production in such GVCs as well. ${ }^{75}$ In various cases, service companies seek to source their inputs internationally. For instance, financial services suppliers may offshore analytical tasks, and particularly back-office data management. Likewise, architects are found to offshore certain of their design works, and doctors to offshore the interpretation of X-ray images. ${ }^{76}$

The business services sector is a striking example to illustrate the segmentation of services production. The OECD has characterized the roles of

71 Charles Stabell and Øystein Fjeldstad (1998), 'Configuring Value for Competitive Advantage: On Chains, Shops, and Networks', 19(5) Strategic Management Journal 413-37, at 416-20.

72 Ibid, at 420 and 427.

73 Richard Baldwin and Anthony Venables (2013), 'Spiders and Snakes: Offshoring and Agglomeration in the Global Economy', 90(2) Journal of International Economics $245-54$.

74 See Miroudot and Cadestin, supra note 9, at 28-9.

75 Koen De Backer and Sébastien Miroudot (2014), 'Mapping Global Value Chains', ECB Working Paper Series No. 1667, at 14.

76 See Heuser and Mattoo, supra note 10, at 142. 
countries in GVCs regarding two segments of this sector, computer and related activities, and other business services. ${ }^{77}$ Though the main market for business services is in developed economies, the industry has been globalized - certain business services are offshored to developing economies, where qualified labor is available at lower costs. ${ }^{78} \mathrm{~A}$ higher tradability of these services allows multinational enterprises to establish global integration competence centers in one country and serve their foreign affiliates via new communication tools. ${ }^{79}$

\subsubsection{The Digitalization of Production and Trade}

In reality, there is no official definition to describe the digitalization of production and trade. Such terms as e-commerce, digital trade or digital economy are frequently used in a flexible way. A narrow definition views digital trade as that in digitalized products, but a broader one may consider it as the use of ICT in conducting business. ${ }^{80}$ Although there is a disharmony in terminology, it is quite commonly agreed that servicification of manufacturing is inherently related to digital technologies. The development of ICT allows enterprises to automate production, increase productivity, and change the way they create value. Digital trade allows firms, particularly smaller ones, to enter distant markets and cut business costs through enhancing GVCs' efficiency. ${ }^{81}$

The most visible change is the transformation of merchandise trade patterns that ICT advancement has brought about through the emergence of 'digitalizable goods', which include many software and media products. The United Nations Economic and Social Commission for Asia and the Pacific (UNESCAP) estimates that cross-border trade in digitalizable products accounts for 0.3 percent of the world's trade in goods in 2014. ${ }^{82}$ However, digital downloads of these products may be classified as part of services trade, such as under the 'personal and recreational services' category. Indeed, software has not been recorded as trade in goods by many countries in recent years. Meanwhile, statistics on services trade has shown that the value of per-

\footnotetext{
77 See De Backer and Miroudot, supra note 75, at 18-30.

78 Ibid, at 28.

79 See Miroudot and Cadestin, supra note 9, at 12.

80 While the term 'digital trade' is widely used by the OECD, the US International Trade Commission, the EU, or McKinsey Global Institute, the term 'electronic commerce' or 'e-commerce' is used by the WTO and UNCTAD. In this book, they are used interchangeably. See UNESCAP, infra note 82, at 107.

${ }_{81}$ See Miroudot and Cadestin, supra note 9, at 12.

82 UNESCAP (2016), Chapter 7 - 'International Trade in a Digital Age', in Asia-Pacific Trade and Investment Report: Recent Trends and Developments, at 109. The report is available at: http://www.unescap.org/sites/default/files/aptir-2016-ch7 .pdf (visited 5 March 2018).
} 
sonal and recreational services exported globally over the period of 2006-2015 significantly increases from 25 to 40 billion US dollars. ${ }^{83}$ It is inferable that trade in digitalizable products has shifted from the sphere of goods to that of services, resulting in a higher share of services in world trade.

Digitalization does not just affect trade in digitized goods or personal and recreational services; in fact, the provision of many services is also influenced. Apparently, in these days, conducting both digital and conventional business relies heavily on inputs from such sectors as information or telecommunications. To be specific, in the tourism and hospitality industry, more and more tickets, hotels and tours are now booked and paid online. E-banking and the provision of insurance services via the internet have become prominent in the finance and insurance sector. Certain professional services, e.g., legal and medical services are growingly relying on internet-based communications. ${ }^{84}$ More remarkably, the digitalization in trade has also turned some non-tradable services into tradable since technological changes have reduced the need for physical presence and simultaneity in the supply and consumption of services, a limitation arising from their non-storability. ${ }^{85}$ To illustrate, medical and educational services used to be considered difficult to supply across border due to the need for direct contact, but they have now become tradable in the form of tele-health and online courses.

Given their large scope, cross-border trade in internet-enabled service sectors accounts for about 88 percent of total world trade in commercial services. ${ }^{86}$ It is estimated that in the Asia-Pacific area, the digital content in exports in 11 services industries has increased more than 100 percent over the period of 1995-2011, while the growth of that content in educational services is nearly 200 percent. ${ }^{87}$

Digitalization has an interconnection with the trend of internationalization of services inputs. Services are often perceived to be less vertically specialized due to the need for direct contact between suppliers and clients. As a matter of fact, a substantial share of the services market is dominated by small domestic firms that supply services directly to local clients using restricted foreign inputs. ${ }^{88}$ However, the scenario has changed in recent years - services production and provision have become much more fragmented. The offshoring of

\footnotetext{
Ibid, at 110 .

Ibid.

85 Americo B. Zampetti and Pierre Sauvé (2006), 'Rules of Origin for Services: Economic and Legal Considerations', in A. Estevadeordal et al. (eds), The Origin of Goods (London: Oxford University Press) 114-45, at 120.

86 See UNESCAP, supra note 82, at 110.

88 See De Backer and Miroudot, supra note 75, at 7.
}

87 Ibid. 
intermediate services to specialized suppliers becomes more feasible for trade in services due to the development of digital trade. Nowadays, a Chinese firm may have a law firm in Italy to draft their contracts, or an Indian firm may be hired to maintain a French company's website. Such practice will not be feasible in the absence of digitalization. The application of ICT in trade has allowed services production to be 'separated from consumption and scaled up, creating final services with higher value added' ${ }^{8}{ }^{8}$

Digitalization also embraces the development of value networks and value shops. Due to ICT advances, these days there are new services provided via the internet or mobile applications. For example, Uber can be seen as a firm providing transport service, but the value in its business model comes from a platform that helps to connect users and drivers, and to organize the ride and payment in a convenient way for customers. ${ }^{90}$ A more significant example showing the role of digitalization to value networks is where the former permits customers to become active participants in the ecosystem to create value. For example, the LEGO Group uses a web portal to design new models of toys on the basis of ideas submitted by its fans. Such a network enabled it to become the world's largest toy company in $2015 .{ }^{91}$ As for value shops, the internet helps to solve the problem of location, which is crucial for this model of value creation. The reason is that online accessibility makes it easier to approach location-specific knowledge and skills. ${ }^{92}$

\section{BOX 1.2 THE CASE OF 3D PRINTING}

The digitalization of trade has blurred the separation between merchandise trade and services trade. Three-dimensional printing (3DP) provides a striking example for such transformation in trade and production. 3DP refers to the manufacturing technique in which $3 \mathrm{D}$ objects are 'printed' by multiple layers of 'ink' based on a specific computer-aided design (CAD). To put it simply, 3DP involves a process where the image created by CAD software is sent to a $3 \mathrm{D}$ printer that builds the product by placing thin layers of mate-

\footnotetext{
89 See SNBT (2013), supra note 3, at 8.

90 Benjamin Edelman and Damien Geradin (2016), 'Efficiencies and Regulatory Shortcuts: How Should We Regulate Companies Like Airbnb and Uber', 19(2) Stanford Technology Law Review 293-328, at 297.

${ }_{91}$ Eamonn Kelly (2015), 'Business Ecosystems Come of An Age', Business Trends Series (Deloitte University Press), at 7-8, available at: https://www2.deloitte .com/content/dam/insights/us/articles/platform-strategy-new-level-business-trends/ DUP_1048-Business-ecosystems-come-of-age_MASTER_FINAL.pdf (visited 8 April 2020).
}

92 See Miroudot and Cadestin, supra note 9, at 28. 
rial one by one. 3DP technology may be used to directly build products, or it can be applied as indirect steps in combination with conventional manufacturing. Notably, the most important difference between 3DP and traditional manufacturing techniques is the creation and the transfer of CAD files, possibly across border, without which the production will not take place. ${ }^{93}$

3DP transforms production processes through the inclusion of various services-related tasks. As a matter of fact, 3DP manufacturers use software solutions which enable the precise measuring and customizing of the objects for individual customers, and finally print the tailored products. ${ }^{94}$ Besides, a further shift towards services occurs when the 3D printer is used by a service supplier treating the client. For example, in the field of dental services, normally the physician will send a cast of his client's jaw to one dental engineer to make the implant. By using 3DP techniques, the physician can also design the implant and print it at his clinic. In this manner, 'the dentist - a service provider - has taken over the task of manufacturing'. ${ }^{95}$

By enabling the digital economy to 'move from the world of data to the physical world', arguably, 3DP further blurs the boundary between manufacturing and services. ${ }^{96}$ It is notable that the question as to whether an offering is a good or a service may not be an issue for a business. However, for statistics and trade policy purposes, that distinction is important as it may challenge basic perceptions of trade. Hence this technology has 'the potential to transform manufacturing processes, reconfigure global supply chains and give rise to business models that are hard to imagine today'. ${ }^{97}$

It is expected that 'the breakthrough of 3DP and consumer products being $3 \mathrm{D}$ printed will come in $2025^{,} .^{98}$ Approximately 67 percent of producers are applying 3DP. Although a high number of them are still in the pilot stage, 'the technology has moved beyond its initial focus on design and prototyping applications of 3DP toward creating more and more finished products, either as final products or as input into other goods (parts)' ${ }^{99}$

93 SNBT (2016), Trade Regulation in a 3D Printed World (Stockholm: National Board of Trade), at 9, available at: http://unctad.org/meetings/en/Contribution/dtl _eweek2016_Kommerskollegium_en.pdf (visited 27 December 2019).

94 See SNBT (2015), supra note 22, at 15-16.

Ibid, at 16.

Ibid, at 6.

97 Marc Sachon (2016), 'Additive Manufacturing Reconfigures Industrial Operations - 3D Printing: The Digitalization of Manufacturing', IESE Alumni Magazine No. 141, available at: http://www.iese.edu/Aplicaciones/upload/ ENAlumniMagazine1413DPrinting.pdf (visited 19 March 2018).

98 See SNBT (2016), supra note 93, at 9.

99 Ibid, at 14. 


\subsection{THE PREFERENTIAL LIBERALIZATION OF SERVICES TRADE}

\subsubsection{The Landscape of Preferential Trade Agreements (PTAs) Covering Services}

The commitments under the GATS differ substantially from those under the General Agreement on Tariffs and Trade (GATT) as a Member's obligations on liberalizing trade in services (including national treatment and market access) only apply to the sectors that it decides to cover in the Schedule of Commitments, and in most cases are subject to further limitations or conditions. As a result, many service sectors are not covered by any GATS market access commitments and remain 'unbound', i.e., no market access is guaranteed to other Members. Indeed, the majority of WTO Members provide no market access commitments in the majority of sectors, resulting in the stagnancy of multilateral liberalization of service trade. ${ }^{100}$

In contrast, regional liberalization has experienced impressive growth in the past two decades. The 'new generation' PTAs covering services component are proliferating all over the world. ${ }^{101}$ As of February 2020, according to the WTO's database, 152 in force PTAs notified to the WTO include services in their scope, roughly one-fourth of which (37) were notified in recent years (2014-2019). Most of these PTAs cover both goods and services from the beginning; for instance, the agreement between Canada and the EU, which was notified in August 2017. Yet, some PTAs expand their scope to include services after the initial agreements only covering goods have been notified. To cite an example, the free trade agreement (on goods) between the Association of Southeast Asian Nations (ASEAN) and India had been notified in August 2010, five years before their economic integration agreement (on services) was notified in August 2015. ${ }^{102}$

The World Trade Report 2011 reveals that out of 85 service PTAs notified to the WTO by that time, more than 30 percent follow the structure of the GATS,

100 Martin Roy, Juan Marchetti and Aik Hoe Lim (2008), 'The Race towards Preferential Trade Agreements in Services: How Much Market Access is Really Achieved?', in Marion Panizzon et al. (eds), GATS and the Regulation of International Trade in Services (Cambridge: Cambridge University Press) 77-110, at 80.

101 Carsten Fink (2008), 'PTAs in Services: Friends or Foes of the Multilateral Trading System?', in Martin Roy and Juan Marchetti (eds), Opening Markets for Trade in Services: Countries and Sectors in Bilateral and WTO Negotiations (New York: Cambridge University Press) 113-47, at 113.

102 WTO, Regional Trade Agreements Information System, available at: http://rtais .wto.org/UI/PublicSearchByCrResult.aspx (visited 6 February 2020). 
with a set of obligations on, for instance, national treatment and domestic regulation, covering the four modes of supply and schedules of commitments based on the positive list modality. ${ }^{103}$ Nearly half of these 85 PTAs follow the structure which is similar to the North American Free Trade Agreement (NAFTA). ${ }^{104}$ They apply different sets of obligations to services trade, and use the negative list modality to schedule commitments. A NAFTA-type PTA often features one chapter on cross-border trade in services, one chapter on investment that covers all sectors (including investment in services), and other chapters on temporary entry of business persons, telecommunications, and financial services. The remaining 20 percent of these PTAs, particularly ones between the EU and its candidate countries, are not categorizable as following the GATS or the NAFTA model since they aim at deeper regional integration. ${ }^{105}$

The difference in the modalities for the scheduling of commitments does have certain implications. The positive list modality implies the obligations in the PTAs only cover the service sectors specified in the schedules of commitments. Meanwhile, the negative list approach means the obligations apply to all sectors, subject only to any reservation indicated explicitly. In other words, the positive list only covers what is listed, whereas the negative list covers everything apart from what is listed. ${ }^{106}$ Hence, as noted by Roy and Marchetti, a PTA adopting the negative list modality is expected to generate more transparency and predictability than the GATS since the market access conditions are guaranteed for 'all but a few' sectors. ${ }^{107}$

Over time, many PTAs have, however, innovated in terms of scheduling modalities and approaches. Various PTAs, notably those recently signed by the US, combine elements of both the GATS and NAFTA models by using the negative list modality and featuring an obligation on market access inspired by the GATS which applies to all supply modes. In particular, Japan's PTAs

103 WTO (2011), World Trade Report: The WTO and Preferential Trade Agreements: From Co-existence to Coherence (Geneva: WTO Publications), at 133.

104 NAFTA is an agreement signed by Canada, Mexico, and the US, which entered into force on January 1, 1994 and has been updated in 2018. Full text of NAFTA is available at: https://www.nafta-sec-alena.org/Home/Texts-of-the-Agreement/North -American-Free-Trade-Agreement (visited 10 January 2020).

105 It is noted that most PTAs involving the US do not have separate chapters on the temporary entry of business persons. See WTO, supra note 103, endnotes 18 and 19, at 154.

106 See WTO, supra note 103, at 133.

107 Martin Roy and Juan Marchetti (2008), 'Services Liberalization in the WTO and in PTAs', in Martin Roy and Juan Marchetti (eds), Opening Markets for Trade in Services: Countries and Sectors in Bilateral and WTO Negotiations (New York: Cambridge University Press) 61-112, at 74. 
with Thailand and the Philippines seek to utilize the assets of both modalities by scheduling their commitments on a GATS basis, and exchanging alongside the 'comprehensive, non-binding lists of non-conforming measures affecting services trade and investment' to promote greater regulatory transparency. ${ }^{108}$

Moreover, regardless of the positive list or negative list modality that they take, many PTAs introduce certain additional sector-specific provisions. Examples can be found in provisions on mutual recognition in a number of PTAs, provisions pertinent to express courier services in PTAs involving the US, ${ }^{109}$ or those pertinent to sea transport services in the EU and the CARIFORUM states. ${ }^{110}$

Beyond those differences and innovations in structure or market liberalizing methods, most of the PTAs tend to share a large similarity among themselves and with the GATS. They often embrace basic disciplines governing trade in services, including scope and definitions, market access, national treatment, domestic regulation, exceptions, etc. In addition, as Roy and Marchetti remarked, "the multifaceted nature of trade in services has resulted in the inclusion of distinct but complementary sets of disciplines to cater for the existence of, inter alia, several modes of supplying services as well as complex sectoral issues'. ${ }^{111}$ Therefore, commitments on the liberalization of trade in services are often incorporated in inclusive PTAs covering not only chapters on trade but also ones on investment, movement of natural persons, or financial services, etc. These chapters either provide specific obligations for, or clarify the application of certain disciplines to those policy areas or sectors. ${ }^{12}$

Beyond the proliferation of PTAs, a group of 23 WTO Members accounting for 70 percent of global trade in services are engaged in the discussions launched in 2013 on a potential Trade in Services Agreement (TiSA). As a sector-specific plurilateral agreement, TiSA is expected to level the playing field and set new standards for services trade that may eventually be brought

108 Pierre Sauvé (2006), 'Been There, Not (Quite) (Yet) Done That: Lessons and Challenges in Services Trade', NCCR Working Paper No.18 (Bern: National Centre of Competence in Research), at 22.

109 See WTO, supra note 103, at 134. See also Ruosi Zhang (2008), 'The Liberalization of Postal and Courier Services', in Martin Roy and Juan Marchetti (eds), Opening Markets for Trade in Services: Countries and Sectors in Bilateral and WTO Negotiations (New York: Cambridge University Press) 378-404, at 397.

110 Economic Partnership Agreement between the CARIFORUM States and the European Community and its Member States, Article 109, available at: http://trade.ec .europa.eu/doclib/docs/2008/february/tradoc_137971.pdf (visited 20 January 2020).

111 See Roy and Marchetti, supra note $10 \overline{7}$, at 74 .

112 Ibid. 
into the multilateral system. ${ }^{113}$ It attempts to open markets and enhance rules in a variety of areas namely financial services, telecommunications, sea transport, e-commerce, and the temporary stay of individuals to supply services. More than 20 negotiating rounds have been conducted up to now, covering a broad range of issues relating to market access and new (or improved) regulation for trade in services. The structure of TiSA is basically developed from the GATS, with all negotiated terms being in line with the latter, including 'scope, definitions, disciplines related to market access and national treatment, as well as exceptions'. ${ }^{114}$

\subsubsection{How Liberal Are PTAs Covering Services?}

Commitments in PTAs provide a level of preferences which is largely better than those provided by the GATS, taking the form of new bindings for sectors not yet committed in the parties' GATS schedules (GATS-X), or higher bindings for sectors already covered by their GATS schedules (GATS+). Some studies acknowledge that PTA commitments on services generally transcend GATS commitments now in force, and even transcend the offers hitherto proposed in the Doha Development Agenda (DDA). ${ }^{115}$

To be specific, by screening the services commitments undertaken in 28 PTAs, Roy et al. examine the average share of sub-sectors being committed under the GATS, under Doha offers and under PTAs for Modes 1 and 3. The figures show that, in terms of the width of commitments, PTAs have brought significant advances to both supply modes. In terms of sectoral coverage, the contribution of PTAs is also impressive. On average, sectoral coverage reaches 73 percent for Mode 1 and 85 percent for Mode 3, doubling that achieved by the Doha offers and by existing GATS commitments respectively. ${ }^{116}$

By investigating schedules of services commitments in 56 PTAs, Miroudot et al. also find that on average, preferential services commitments surpass the GATS. Strikingly, 72 percent of 155 sub-sectors covered by these 56 PTAs have commitments on market access and national treatment, and the

113 Rachel F. Fefer (2017), 'Trade in Services Agreement (TiSA) Negotiations: Overview and Issues for Congress', Congressional Research Service Report, at 6. The 23 WTO Members include: Australia, Canada, Chile, Chinese Taipei, Colombia, Costa Rica, the EU, Hong Kong China, Iceland, Israel, Japan, Korea, Liechtenstein, Mauritius, Mexico, New Zealand, Norway, Pakistan, Panama, Peru, Switzerland, Turkey, and the United States.

114 European Commission, Trade in Services Agreement (TiSA) Factsheet, available at: http://trade.ec.europa.eu/doclib/docs/2016/september/tradoc_154971.doc.pdf (visited 27 January 2020).

115 See, for instance, Roy et al., supra note 100; Roy and Marchetti, supra note 107.

116 See Roy et al., supra note 100, at 81-2. 
commitments are GATS + in 42 percent of the sub-sectors. The levels of commitments are found to vary across modes of supply: fewer bindings are made under Modes 1 and 2, but they are usually in sub-sectors not covered by PTA parties' GATS schedules; whereas, the bindings under Modes 3 and 4 cover more sub-sectors but they are generally GATS+ ones. Distribution and business services are the sectors with the highest level of GATS+ commitments, whereas transport, recreational, cultural and sporting, and health and related services are those with particularly high levels of GATS-X bindings. In terms of construction and financial services, PTAs often bring forth improved commitments rather than new ones. ${ }^{117}$

Regarding commitments by sector, in general, there are more bindings at the sectoral level for Mode 1 and Mode 3 in PTAs as compared to the GATS. Notably, sectors that are more challenging to negotiate at the GATS level (e.g., education, audiovisual) have also allured fewer GATS + bindings than those sectors such as telecommunications or financial services. Yet, preferential commitments for these challenging services still go remarkably beyond GATS ones in spite of the fact that in PTAs involving large trading partners, the more sensitive sectors (e.g., maritime transport for the US or audiovisual services for the EU) are often subject to little or no improvement. ${ }^{118}$ Besides, PTAs have made progress with regard to government procurement in services, but the disciplines for this are not part of PTAs' services chapters. ${ }^{119}$

As investigated by the WTO, the average level of sectoral coverage attained in PTAs is not different among developed and developing partners, but the dissimilarity with the GATS commitments is more visible for developing ones, since they often commit under fewer service sub-sectors at the multilateral level. ${ }^{120}$ Besides, the state of development does tend to shape the features of PTA partners' GATS + commitments. For developed economies, owing to their deeper GATS commitments, GATS + commitments in PTAs tend to be more limited, which mainly improves the level of bindings in sectors already covered by their GATS schedules. In contrast, for developing ones, there is a spread of GATS + bindings across all sectors, with marked advances 'in business, environmental services, distribution, education, and postal-courier services'. ${ }^{121}$ Without any prejudice to this finding, the commitments of each

117 Sébastien Miroudot, Jehan Sauvage and Marie Sudreau (2010), 'Multilateralizing Regionalism: How Preferential Are Service Commitments in Regional Trade Agreements?', OECD Trade Policy Papers No. 106 (Paris: OECD Publishing), at 5.

118 Ibid.

119 See Roy and Marchetti, supra note 107, at 74.

120 See WTO, supra note 103, at 134.

121 Ibid. There are certainly counter-examples to this overall trend. For instance, the ASEAN countries (except for Singapore), introduce rather limited GATS+ commitments in their PTAs. 
WTO Member also differ across PTAs. To cite an example, Singapore's commitments vary noticeably in its PTAs with the US, Japan, and other ASEAN partners. Considerable variations are also identified in preferential services commitments of Australia, Chile and South Korea. ${ }^{122}$

Despite the fact that PTA commitments are less significant for Mode 4 as compared to other modes of supply, it is evidenced that except for the US (in its more recent PTAs), several Asian countries, and the European Free Trade Association (EFTA), other WTO Members' preferential commitments have gone beyond their GATS bindings, or even their latest DDA offers, although such advances are not sizable. ${ }^{123}$ Besides, since Mode 4 commitments are usually defined in a cross-sectoral manner in both the GATS and PTAs, a broader sectoral coverage of most PTAs may extend Mode 4 commitments to a number of previously uncommitted sectors. ${ }^{124}$

About the framework of 'rules' governing trade in services, most agreements have not drifted far from the GATS in disciplining services subsidies or allowing for emergency safeguard measures. They also provide no extensive additional provision on domestic regulation, transparency and mutual recognition. ${ }^{125}$ There are yet some examples that embody GATS + commitments, for instance, a necessity test on domestic regulation in the PTA between Switzerland and Japan, or additional services-specific provisions on transparency in many agreements involving the US. ${ }^{126}$

Finally, PTAs are sometimes GATS-minus, which means they consist of commitments providing for less than what is bound under the GATS. In general, there are four types of GATS-minus commitments: (1) tightening the existing GATS limitations, (2) setting additional restrictions not listed under GATS commitments, (3) omitting sub-sectors or sector segments, and (4) including reciprocity elements. ${ }^{127}$ For instance, the Economic Partnership

122 Ibid, at 136.

123 Antonia Carzaniga (2008), 'A Warmer Welcome? Access for Natural Persons under PTAs', in Martin Roy and Juan Marchetti (eds), Opening Markets for Trade in Services: Countries and Sectors in Bilateral and WTO Negotiations (New York: Cambridge University Press) 475-502, at 496-9.

124 See WTO, supra note 103, at 136.

125 See WTO, supra note 103, at 134 and Roy and Marchetti, supra note 107, at 74 .

126 The provisions mentioned can be found in the Agreement on Free Trade and Economic Partnership between Japan and the Swiss Confederation, Article 48, available at: http://www.mofa.go.jp/region/europe/switzerland/epa0902/agreement .pdf (visited 20 January 2020); and, for instance, in the United States - Peru Trade Promotion Agreement, Article 11.8, available at: https:/ustr.gov/sites/default/files/ uploads/agreements/fta/peru/asset_upload_file234_9537.pdf(visited 20 January 2020).

127 Rudolf Adlung and Peter Morrison (2015), 'Poison in the Wine? Tracing GATS-minus Commitments in Regional Trade Agreements', WTO Staff Working Paper ERSD-2012-04, at 16. 
Agreement between Japan and Thailand introduces several GATS-minus elements. Most apparently, in its Services Schedule Thailand lowers the foreign equity ceilings for telecommunication services from 40 percent (GATS) to 25 percent. $^{128}$

\subsubsection{The Connection between Investment Chapters and Trade in Services Chapters}

As mentioned above, 'new generation' PTAs cover not only trade in goods and services, but also investment and even other non-trade issues. Since trade in services via Mode 3 involves the constitution and/or maintenance of a 'commercial presence' in another country, this mode of supply in fact relates to investment in the field of services. Thus, in PTAs where both investment and services trade are covered, how will the two areas interact, and will there be an overlapping? Given the dominant share of Mode 3, these questions prove to be crucial for the origin determination of services in PTAs. By nature, in PTAs where establishment-related services transactions are provided in the investment chapter instead of the trade chapter, rules of origin (ROO) for this mode of supply may be found in the investment chapter. The notion of origin becomes even more complex where the establishment-related supply of services is included in both chapters.

Pursuant to Houde et al., investment and trade in services chapters in PTAs inspired by the GATS and NAFTA differ in their structure and coverage, which entails different forms of interaction. ${ }^{29}$

NAFTA-inspired PTAs: In these PTAs, there is a sharp separation between chapters on investment and those on cross-border trade in services with an aim to restrict their interaction. The former will govern investment disciplines on both manufacturing and services sectors (normally with an exception of financial services), whereas the latter is devoted to liberalizing services trade delivered via all modes but commercial presence. ${ }^{130}$ In other words, Mode 3 supply of services is treated under the regime for investment.

NAFTA itself is the most illustrative example of PTAs with no interaction between the trade in services and the investment chapters. However,

128 WTO Committee on Regional Trade Agreements (2011), Factual Presentation: Economic Partnership Agreement between Japan and Thailand (Goods and Services) (document WT/REG235/1, dated 18 April 2011), at 37.

129 Marie-France Houde, Akshay Kolse-Patil and Sebastien Miroudot (2008), 'The Interaction Between Investment and Services Chapters in Selected Regional Trade Agreements', in International Investment Law: Understanding Concepts and Tracking Innovations (Paris: OECD Publishing) 241-340, at 245-7.

$130 \mathrm{Ibid}$, at 245. 
NAFTA-inspired PTAs recently concluded do allow for a limited interaction. For instance, some clauses in the chapter on cross-border services trade in the PTA between the US and Morocco (market access, domestic regulation, and transparency) apply to the investment chapter under certain conditions. ${ }^{131}$ A clause on the 'relation to other chapters' is also included to clarify that other chapters prevail in case there is any inconsistency with the investment chapter. ${ }^{132}$ Besides, though financial services are provided in a separate chapter, some provisions of the investment and the services trade chapters are incorporated to this sector. ${ }^{133}$

GATS-inspired PTAs: GATS-inspired PTAs generally cover investment and trade in services in separate chapters, but investment in services is normally governed by both disciplines. In such PTAs, the supply of services, including via commercial presence, is governed by chapters on cross-border services trade. Meanwhile, clauses on protection of investment in services, particularly expropriation, compensation for damages, and dispute resolution, are provided by investment chapters. ${ }^{134}$ In resonance with the form of trade and investment interaction, GATS-inspired PTAs can be divided further down as follows:

The interaction is defined in the investment chapter: This option is adopted by a large number of GATS-inspired PTAs. The chapters on services trade come first and contain market access and national treatment obligations toward commercial presence, while the chapters on investment define their coverage and provide rules to handle potential inconsistency with the services trade chapters. ${ }^{135}$ This approach is adopted, for instance, in the PTA between New Zealand and Singapore: the commitments in the investment chapter will not apply to any measure affecting the investments already regulated by the chapter on services trade to the extent that 'they relate to the supply of any specific service through commercial presence'. ${ }^{136}$

The interaction is defined in the trade in services chapter: This option is adopted in a fewer number of PTAs, in which the interaction is embodied via a 'service-investment linkage' clause in the chapter on services trade. This type of interaction may minimize the possibility of inconsistency between the

131 United States - Morocco Free Trade Agreement, Article 11.1(3), available at: https://ustr.gov/sites/default/files/uploads/agreements/fta/morocco/asset_upload _file680_3841.pdf (visited 19 January 2020).

132 Ibid, Article 10.2(1).

133 Ibid, Article 12.1(2).

134 See Houde et al., supra note 129, at 246.

135 Ibid.

136 Agreement between New Zealand and Singapore on a Closer Economic Partnership, Article 26, available at: https://www.mfat.govt.nz/assets/FTAs-agreements -in-force/Singapore-FTA/NZ-Singapore-CEP-full-text.pdf (visited 19 January 2020). 
two areas by indicating liberalization and protection obligations governing the investment in services. ${ }^{137}$ To illustrate, in the PTA between India and Singapore, certain provisions on investment such as expropriation or compensation for damages 'shall apply mutatis mutandis to measures affecting the supply of service through commercial presence in the territory of the other party'. ${ }^{138}$

No interaction is defined: This approach is often found where investment is concluded as an agreement separated from the PTA containing the services in trade chapter. For instance, the clauses on transfers are found in both the PTA and the investment treaty between EFTA and Korea, with one being less permissive than the other. ${ }^{139}$ In addition, this approach is also adopted in certain PTAs which cover investment, such as the one between Singapore and Japan. In this agreement, the services trade chapter lays down obligations regarding four modes of supply, while the investment chapter governs the measures affecting investment (excluding government procurement and movement of natural persons who are investors). There is no provision to handle a potential conflict between them. ${ }^{140}$ Houde et al. remark that this approach counts entirely on 'the rules of interpretation of international law' to clear up the connection between the chapters on investment and services trade. Such a lack of clarity may cause confusion; thus recent PTAs tend to abandon this approach and favor a more precise and explicit one. ${ }^{141}$

It is noted that PTAs involving the EU and the EFTA countries (Iceland, Liechtenstein, Norway and Switzerland) largely adopt the GATS approach, but unique features have separated them from other GATS-based PTAs. ${ }^{142}$ To illustrate, in the PTA between the EU and Chile, there are chapters governing trade in services and investment that cover all modes of supply, financial ser-

137 See Houde et al., supra note 129, at 246-7.

138 Comprehensive Economic Cooperation Agreement between the Republic of India and the Republic of Singapore, Article 7.24, available at: http://investmentpolicyhub .unctad.org/Download/TreatyFile/2707 (visited 19 January 2020).

139 Free Trade Agreement between the EFTA States and the Republic of Korea, Article 3.13, available at: http://www.efta.int/media/documents/legal-texts/free-trade -relations/republic-of-korea/EFTA-\%20Republic\%20of\%20Korea\%20Free\%20Trade \%20Agreement.pdf (visited 19 January 2020); Agreement on Investment between the Republic of Korea and the Republic of Iceland, the Principality of Liechtenstein and the Swiss Confederation, Article 5, available at: http://www.efta.int/sites/ default/files/documents/legal-texts/free-trade-relations/republic-of-korea/Investment \%20Agreement/Investment\%20Agreement.pdf (visited 19 January 2020).

140 Agreement between Japan and the Republic of Singapore for a New-Age Economic Partnership, Chapters 7 and 8, available at: http://www.mofa.go.jp/region/ asia-paci/singapore/jsepa-1.pdf (visited 19 January 2020).

${ }_{141}$ See Houde et al., supra note 129, at 247.

142 Ibid. 
vices and establishment. However, the establishment chapter opts to preclude services from its coverage - it applies to 'establishment in all sectors with the exception of all services sectors, including financial services sector'. ${ }^{143}$ The same provision is also found in the PTA between EFTA states and Chile, in which the establishment chapter narrows down its scope by ruling out investment in services sectors. ${ }^{144}$ These PTAs are peculiar because an inclusion of four modes of supply in the chapter on services trade is similar to the GATS, but the exclusion of investment in all services sectors to eliminate interaction is closer to NAFTA.

\subsection{NEW PATTERNS OF TRADE AND THE NECESSITY TO RETHINK ROO FOR SERVICES}

Before diving into various aspects of ROO for services in the next chapters, one may pose the question whether this topic is worth discussing. As mentioned in the Preface, ROO for services are an area of rule making that has received insufficient attention from trade scholars. This is partly because pioneer authors tend to make a prejudgment that ROO have 'no significant economic effects' on services trade, particularly as compared with merchandise trade. ${ }^{145}$ There are probably several reasons underlying this prejudgment: (1) services trade was much less important back in the early 1990s, rendering ROO for services deemed unimportant then; (2) there is little basis for origin-based measures in services trade; and (3) trade in goods and trade in services are widely considered as separate spheres, thus ROO in each field are not related. In fact, what has been discussed so far has shown that the state-of-art of services trade has evolved over the past few decades. The new context of trade and production will prompt the need to rethink the relevance of ROO for services.

Firstly, the emergence of GVCs has brought changes to the way firms carry out their business activities and the patterns in which trade and production are conducted. The discussion above indicates that in the world of GVCs, trade and production are highly servicified, i.e., they intensively rely on services,

143 Agreement Establishing an Association between the European Community and its Member States and the Republic of Chile, Article 130, available at: http://eur-lex .europa.eu/resource.html?uri=cellar:f83a503c-fa20-4b3a-9535-f1074175eaf0.0004.02/ DOC_2\&format=PDF (visited 19 January 2020).

${ }_{144}$ Free Trade Agreement between the EFTA States and the Republic of Chile, Article 32, available at: http://www.efta.int/media/documents/legal-texts/free-trade -relations/chile/EFTA-Chile\%20Free\%20Trade\%20Agreement.pdf (visited 19 January 2020).

145 E. Ivan Kingston (1994), 'The Economics of Rules of Origin', in Edwin Vermulst, Jacques Bourgois and Paul Waer (eds), Rules of Origin in International Trade: A Comparative Study (Ann Arbor: University of Michigan Press) 7-25, at 20. 
particularly when viewed from a TiVA perspective. The phenomenon of servicification indicates that services play an increasingly crucial role in the world economy. Noticeably, this trend has not been reflected in trade rules, trade negotiations, or trade governance structures ${ }^{146} \mathrm{It}$ is expected that, once services have gained economic significance, the need for ROO may at the same time increase. Moreover, since GVCs also transform the nature of services trade and production, it is questionable whether existing ROO for services negotiated over three decades ago remain compatible with new patterns of trade.

The second reason regarding the origin-neutrality of measures affecting services trade is undeniably a valid point to argue that ROO for services are not necessary. As it will be elaborated in the following chapters, trade in goods and trade in services are regulated in rather different manners. Measures in the field of services, e.g., competition related ones, address the whole market and are not selective in terms of partners. ${ }^{147}$ However, a thorough study of the WTO jurisprudence may change this stance, since the issue of services origin has been analyzed in various disputes. In addition, the proliferation of PTAs has made the notion of origin become more important in modern services trade as PTAs are expected to be more selective than the GATS in granting market access. A vivid example is the concern that after the UK leaves the EU, i.e., Brexit, branches of EU banks in the UK may lose 'passporting' rights allowing them to supply financial services in the single market. This might also be the case for branches of UK-based banks in the rest of the EU. They may be considered as foreign bank branches, which potentially affects how they are regulated, what they can do, and what prudential requirements they are subject to. ${ }^{148}$ That is to say, the issue of origin of services may become more crucial with time in different ways, not limited to GATS commitments on non-discrimination.

Regarding the separation of trade in goods and trade in services, the discussion above has shown that the trend of internationalization and digitalization, largely enabled by technology changes, also transforms trade by making goods and services become more intertwined. The essential and growing contribution of 'Mode 5' services embodied in merchandise exports reveals

146 Jane Drake-Brockman and Sherry Stephenson (2012), 'Implications for 21st Century Trade and Development of the Emergence of Services Value Chains', ICTSD Working Paper (Geneva: International Centre for Trade and Sustainable Development), at 31 .

147 Based on the discussion with Sebastian Miroudot (Trade and Agriculture Directorate, OECD).

148 British Bankers' Association (2016), 'What Is "Passporting” and Why Does It Matter?', Brexit Quick Brief Series No. 3, available at: https://www.bba.org.uk/wp -content/uploads/2016/12/webversion-BQB-3-1.pdf (visited 2 February 2020). 
a considerable portion of services being traded indirectly under the regime for goods. On one hand, the fact that goods and services are blended in the era of servicification means that services may have to comply with merchandise trade rules. Most obviously, services indirectly sold in the 'box' of goods are treated as part of goods; therefore, they are subject to customs duties. It means barriers to trade in goods may impede the supply of packages of offerings by servicified manufacturing firms. ${ }^{149}$ On the other hand, that services become an increasing portion of goods may have direct implications for ROO for goods. To determine the origin of goods, it would be a loophole if merchandise ROO fail to take into account the origin of service inputs. For this reason, if ROO for services are not well designed, they may hamper the origin determination of goods. That is to say rethinking ROO for services is not solely for the sake of service trade, but may have an impact on merchandise trade as well. In general, it will help address the need to establish trade rules which are more compatible with the evolvement of trade and production.

Finally, origin of services is expected to become more crucial in the future when trade and production become highly digitalized. The rise of 3DP technology should be taken as an example. It initiates the question of whether the WTO regulatory framework is fit for the development of this new method of production or it is necessary to change the rulebook. Notably, a number of WTO rules do not apply if there are no goods crossing the border. As a matter of fact, the task of producing final products in 3DP will mostly fall on consumers. Since manufacturing is in the same country with consumption, the goods do not cross the border; hence, WTO rules for trade in goods are not applicable. In fact, regulations and commitments for trade in goods will remain relevant only for the imports of printers, spare parts, and 'ink'. ${ }^{150}$

$3 \mathrm{DP}$ removes a number of intermediary goods and replaces them with services inputs, which may involve different activities namely designing CAD files, transmitting digital information, setting up and managing e-markets for those files, etc. Therefore, part of the manufacturing process, as well as the trade associated with the process, no longer falls within the WTO's regulatory framework for merchandise trade, but that for trade in services. The involvement of more services elements in the value chain, which tends to reinforce the role of services trade rules, marks a shift of importance from GATT to GATS. ${ }^{151}$ Apparently, when such service inputs as data files become production inputs, the need to determine their origin will become inevitable.

149 WTO (2013), World Trade Report-Factors Shaping the Future of World Trade (Geneva: WTO Publications), at 293.

150 See SNBT (2016), supra note 93, at 23.

151 Ibid, at 32. 
As current ROO for services are likely inadequate to handle 'trade in data', it is not too early to initiate the quest for a new approach to origin of services. 